members. This is a list of the basic books needed to get to know the Labour History of each member country. We have issued lists of second-hand booksellers, reputable publishers, and at the moment we are engaged in producing a directory of the Socialist Press. We have in mind also the production of a Thesaurus on Labour History terminology. All material we produce is circulated to all members and we hope that the major works will find their way into the national bibliographies.

As to the officers of the association: the secretary is elected for five years with a possible extension of another five years. The chairman for the duration of one year is elected at the annual conference and is always the host. Membership fee is $£ 5.00$ per annum and there is no charge to members attending the conference.

Irene Wagner (Mrs.),

Secretary, Librarian of the Labour Party

\title{
REPORT ON THE SOUTHWEST LABOR STUDIES CONFERENCE
}

The fourth annual Southwest Labor Studies Conference was held in Berkeley on March 17 and 18, 1978. Its sponsoring organization, the Southwest Labor Studies Association, was conceived as a bridge between labor activists-both union officials and members of the rank-and-file-and academics. At times the meeting in Berkeley fulfilled the promise of such an organization.

At its best the interaction between scholars and those who have provided the raw material for the scholars to work with should test interpretation against recalled experience. Yet all too often this sort of conference merely furnishes a forum where people who lack either the ability or the discipline to utilize more traditional forums have their hour of glory. Unfortunately good intentions are no substitute for hard work and thought. One deduces that some pecple think they are. Thus, the spectacle of a "scholar" who riffled through note cards and called this performance a paper or an activist who spent thirty minutes rapping about anything and everything in what was presumed to be a substantive presentation.

It is not necessary that activists have scholarly credentials in order to do creditable work for such occasions. Merely, they must take what they are doing seriously. In a generally excellent session on ethnic labor chaired by David Brody of U.C. Davis, two men with divergent experiences in the labor movement gave exemplary papers. Frank Arnold of the International Association of Machinists reviewed the life and work of Humberto Silex, a Nicaraguan who organized for the CIO in south Texas. Karl Yoneda recounted, in a largely autobiographical paper, the militancy of Japanese farm labor in California, especially in the 1930s. In addition, Michael Kazin, a graduate student at Stanford, analyzed the anti-Chinese riots in San Francisco in 1877.

Because of protests generated at earlier conferences, particular heed was given to the history of women and third world labor. Hence there was considerable emphasis on the experience of Chicano workers. An especially valuable paper came from Alex Saragosa of California State University, Fresno. Entitled, "Chicano Labor in the San Joaquin Valley: a Social History," it emphasized the diversity in the Chicano community and the resultant cultural conflict. 
One can only.hope that future conferences will be better organized and publicized and that all the participants will work hard on their presentations. The idea is too good to be wasted by substituting vague highmindedness for real substance.

\section{REPORT ON WORKSHOP HISTORISCHE MODERNISIERUNGSFORSCHUNG}

On May 26 and 27 the Research Group "Historische Modernisierungsforschung in Deutschland" of the Zentralinstitut für sozialwissenschafliche Forschung at the Freie Universität, Berlin, held a workshop on "The Social Structure of the Working Class in 19th Century Europe". The meeting was sponsored by the Volkswagen Foundation and organized by Hartmut Kaelbe and Hermann-J. Rupieper. The goal of the workshop was to bring together a limited group of social historians currently working on research projects in this field. Hence, the sessions did not focus on the history of working class movements or organizations, but mainly covered questions concerning problems and methods of research during the formation of the working class in Europe. The main topics of the workshop were the geographical and social mobility of workers, internal differences within the working class concerning income, qualification and job security, and the influence of production changes and the diversification of the work process on behavior and attitudes of workers. Another aspect of the meeting was to encourage comparative studies in a European perspective.

An introduction to the main problems of the workshop was given by David Crew (Columbia Uni. versity) with his paper "Some Thoughts on the Comparative Analysis of the Structure and Culture of the Working Class in Selected Industries: England, France, and Germany 1890-1914". Taking metal workers and miners as an example for a comparative approach, Crew showed common developments and differences in the formation of a "European Working Class". He also stressed the importance of dissimilarities even within one branch. However, social background, the difference between skilled and unskilled labor, the influence of the life cycle and role differences as well as family background were seen as some important factors in a comparative approach.

The following papers which were read dealt with developments in Great Britain, Sweden, France, and Switzerland. Geoffrey Crossick (Hull) showed in his paper "An Artisan Elite in the Victorian Social Structure", which presented the findings of a research project dealing with a set of communities in southeast London, that an artisan elite of skilled labor developed during the nineteenth century. In contrast to older studies on the "labor aristocracy", Crossick argued that the social structure of the working class must be defined in ways that go beyond the analysis of skills, pay and job security. His interpretation of an artisan elite incorporated both an economic elite and a social stratum of skilled men which "took on distinctive values, patterns of behavior and social aspirations that distinguished it from other sections of society".

Uno Gustafson (Stockholm) read "Some Remarks on the Social Structure of the Working Class in Nineteenth Century Sweden". Focusing on Stockholm as an example, he showed the influence of industrialization, urbanization and demographic changes upon the growth of a local and regional labor market and the adaption of working men and women to this process. 